\title{
ADAPTIVE PERFORMANCE OF GARLIC VARIETIES UNDER HIGH GANGES RIVER FLOODPLAIN SOIL (CALCAREOUS) OF BANGLADESH
}

\author{
M.S. RAHMAN ${ }^{1}$, M.T. ISLAM ${ }^{2}$, NC. SHIL ${ }^{3}$, M. H. RAHMAN ${ }^{4}$, \\ M. JAHANGIR ALAM ${ }^{5}$, M.R. ISLAM ${ }^{6, *}$ \\ *E-mail: rafiq_bari2@yahoo.com
}

Received: July 13, 2020. Revised: Sept. 29, 2020. Accepted: Oct. 05, 2020. Published online: Oct. 16, 2020

\begin{abstract}
Any variety needs to evaluate at different locations, along with variable soils for asses their yield potentiality after its releasing. Thus, an experiment was conducted at Multi Location Testing (MLT) site, Kushtia Sadar Upazila, under High Ganges River Floodplain (AEZ-11) in Bangladesh, during three consecutive Rabi seasons of 2013-2014 to 2015-2016. The objective of this study was to evaluate the performances of garlic varieties and economic profitability of these varieties at farmer's field. There were three garlic varieties, namely BARI Rashun-1, BARI Rashun-2 and a local cultivar, which were evaluated at six dispersed locations as replications.
\end{abstract}

Results observed that the highest yield (8.34-9.80 $\mathrm{t} \mathrm{ha}^{-1}$ ) was obtained from BARI Rashun-1, which was followed by BARI Rashun-2 (7.43-9.48 $\mathrm{t} \mathrm{ha}^{-1}$ ) and the local one (7.12-9.15 $\left.\mathrm{t} \mathrm{ha}{ }^{-1}\right)$. BARI Rashun-1 produced 3-12\% higher yield over BARI Rashun-2 and 7-20\% over the local cultivar, respectively in three consecutive years. Correlation analysis showed that there were positive and significant correlation among bulb yields with bulb length and individual bulb weight. Regarding the functional relationship, the traits like crop duration, plant population, plant height, bulb length, bulb width, individual bulb weight had positive contribution on the bulb

\footnotetext{
${ }^{1}$ Agricultural Economics division, Pulses Research Centre, Regional Agricultural Research Station, BARI, Ishurdi, Pabna, Bangladesh

2 Pomology Division, Horticulture Research Centre, BARI, Gazipur, Bangladesh

${ }^{3}$ Planning and Evaluation Wing, BARI, Gazipur, Bangladesh

${ }^{4}$ Regional Agricultural Research Station, Bangladesh Agricultural Research Institute (BARI), Jashore, Bangladesh

5 On-Farm Research Division, Gaibandha, BARI, Bangladesh

${ }^{6}$ Agronomy Division, Regional Agricultural Research Station, BARI, Ishwardi, Pabna, Bangladesh
} 
yield. It was dependent on those traits, and accounted for 12, 36, 0.05, 45, 41 and $55 \%$ of the total bulb yield variation, respectively. The highest gross return (Tk. 3, 63,700 $\mathrm{ha}^{-1}$ ) and gross margin (Tk. 2,19,425 ha-1) were obtained from BARI Rashun-1. As such, this variety performed as the best, in respect of higher bulb yield potential, as well as the highest economic return among the tested varieties, which was followed by BARI Rashun-2. Therefore, the result of this study could be helpful for improving bulb production of garlic under High Ganges River Floodplain soil (calcareous soils) in Bangladesh.

Keywords: Allium sativum L.; yield potentiality; functional relationship; economics efficiency; adaptation.

\section{INTRODUCTION}

Garlic (Allium sativum L.) is one of the most important aromatic herbaceous annual spices under the family Alliaceae (Kurian, 1995), which widely used in the Globe including Bangladesh. It is the second most widely used cultivated Allium, after onion (Bose and Som, 1990), with a characteristic of pungent smell. China is the largest garlic producing country in the world, amounting 21.20 million tons per annum, while Bangladesh produces about 3.12 lakh ton, ranking fourth in the world context (FAOSTAT, 2016). Garlic requires cold, but dry weather, with moderate moisture for proper growth. It also requires well drained soil, with high organic matter content. It is sensitive to high humidity, excessive moisture and high temperature, which limits the growth of the crop (Babaji, 1996). Garlic has been known to have several food and medicinal values. Garlic extracts are generally used in curing whooping cough, lung diseases and stomach pain and child birth disorder. The extract could be used against ear-ache, hypertension, eyesores, an antidote against poisons and antibacterial agent, as well as reduced cholesterol level in human blood. It has been recognized, all over the world as a valuable spice for cooking different dishes. Garlic has higher nutritive value than other bulb crops, as it is rich in proteins, phosphorus, potassium, calcium, magnesium, and carbohydrates and hence also finds medicinal usage, especially in treating intestinal diseases (Rahman and Islam, 2016). It contains about 30$35 \%$ dry matter, $6-7 \%$ protein, $0.2 \%$ lipid and 23-28\% carbohydrates (Khatun et al., 2014).

In Bangladesh, during 20162017, the estimated area for garlic was about 66,289 hectares, which is $16.08 \%$ of total spices and condiments areas and its production was 4.25 lakh metric tons with average yielding of 6.42 tha $^{-1}$ (BBS, 2018). But, the production is extremely insufficient in terms of demand and the average yield is quite low, compared to other garlic growing countries. This low yield may be due to the cultivation of the low yielding local varieties, incidence of diseases and insects, lack of technological knowledge of the growers etc. Spices Research Centre, Bangladesh Agricultural Research Institute (BARI) has developed four 
garlic varieties, namely BARI Rashun-1, BARI Rashun-2, BARI Rashun-3 and BARI Rashun-4, which are high yielding varieties (yield potentiality 6-11 $\mathrm{t} \mathrm{ha}^{-1}$ ) and less susceptible to pests and diseases. These varieties expected to be promising in increasing generation of farmers' income in a very short period of time.

The yield potentiality of a variety depends on several factors especially in soil and environmental traits, likes temperature, rainfall and relative humidity. Not only is that variety/genotypes also responsible for yield potentiality (Islam et al., 2015). As garlic cultivated in winter season it face water shortage due to negligible precipitation (Islam and Zaman, 2017). Hence, amount of rainfall, during the growing period, is responsible for yield variation of garlic. Climatic condition also varies one year to another. So, judgment of yield potentiality in a particular variety should be evaluated in several years. However, performance of garlic varieties has not yet been evaluated under different agro-climatic conditions, especially for calcareous soils in Bangladesh. Considering the above perspectives, the present study was conducted to find out the performances of garlic varieties and economic profitability at farm field, along with calcareous soils in three consecutive years.

\section{MATERIALS AND METHODS}

The experiment was carried out at Multi Location Testing (MLT) site of
Kushtia Sadar (Latitude: $23.87736^{0} \mathrm{~N}$; Longitude: 89.09126 $\left.{ }^{\circ} \mathrm{E}\right)$ in Bangladesh, during Rabi season (October to April) of the consecutive three years (2013-2014 to 2015-2016), at farm field conditions. The land was medium high with flood free well drained. The altitude of the experimental site is $17 \mathrm{~m}$ and the maximum and minimum temperature ranged $22.9-38.2^{0} \mathrm{C}$ and $8.5-23.4^{0} \mathrm{C}$, respectively, during the growing period of respective years (Fig. 1).
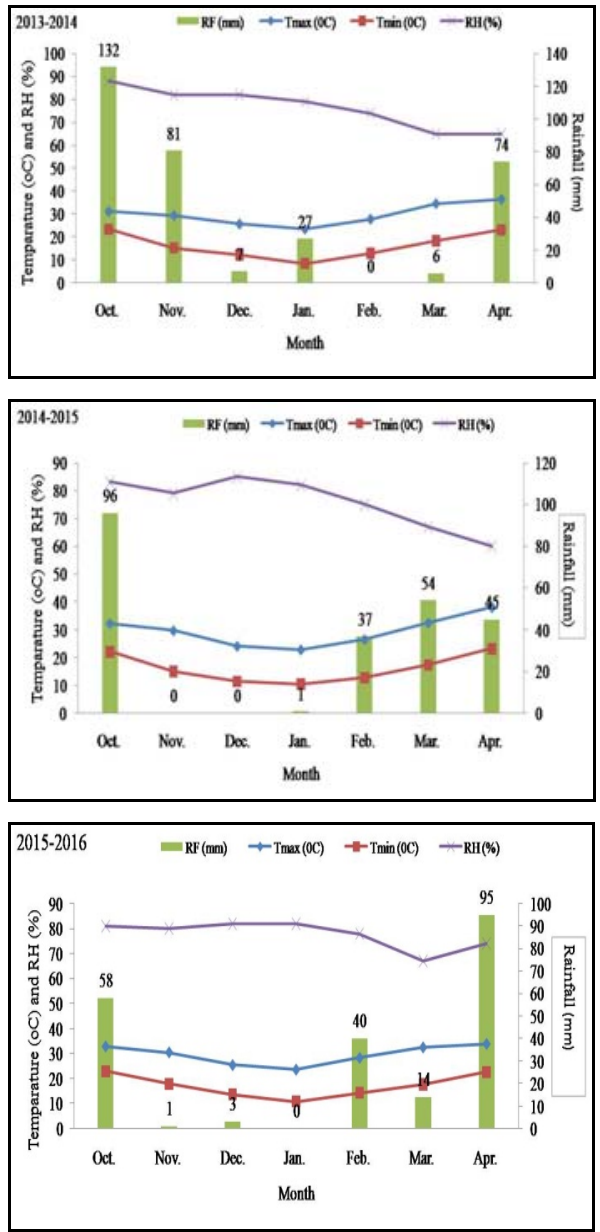

Figure 1 - Monthly climatic scenario during the growing period of garlic experiment (2013-2015) 
Month wise weather parameter, viz., temperature (Tmax and Tmin), total rainfall (mm) and relative humidity (\%), during the period of respective years (2013-2014 to 2015-2016) have been presented in Fig. 1. The soil is calcareous in nature, under High Ganges River Floodplain (AEZ-11). The initial soil chemical properties of the experimental soil have been depicted in Table 1.

Table 1 - Initial soil chemical properties of the experimental soil and their interpretation according to FRG (2012)

\begin{tabular}{|c|c|c|c|c|c|c|c|c|}
\hline \multirow[b]{2}{*}{ Items } & \multirow[b]{2}{*}{$\mathrm{pH}$} & \multirow{2}{*}{$\begin{array}{l}\text { Organic } \\
\text { matter } \\
(\%)\end{array}$} & \multirow{2}{*}{$\begin{array}{c}\mathrm{K} \\
\mathrm{meq} / 100 \\
\mathrm{~g} \text { soil }\end{array}$} & \multirow{2}{*}{$\begin{array}{c}\text { Total } \\
\mathrm{N} \\
(\%)\end{array}$} & $\mathbf{P}$ & $\mathbf{S}$ & $\mathrm{Zn}$ & B \\
\hline & & & & & \multicolumn{4}{|c|}{$\mu g^{-1}$} \\
\hline Initial soil & 7.93 & 2.02 & 0.26 & 0.10 & 10.40 & 19.00 & 0.82 & 0.47 \\
\hline Critical limit & - & - & 0.12 & 0.12 & 10.00 & 10.00 & 0.60 & 0.20 \\
\hline Interpretation & $\begin{array}{l}\text { Slightly } \\
\text { alkaline }\end{array}$ & Medium & Medium & Low & Low & Medium & Low & Medium \\
\hline
\end{tabular}

The experiment was laid out in randomized completely block design, with six dispersed replications. The unit plot size was $6 \mathrm{~m} \times 5 \mathrm{~m}$. Three varieties of garlic, viz. BARI Rashun-1, BARI Rashun-2 and local were tested. The seeds (clove) were planted in 25 November 8 December, 2013-2014; 06-13 December, 2014-2015 and 30 October to 18 November, 2015-2016, with spacing of $15 \mathrm{~cm} \times 10$ $\mathrm{cm}$. The date of sowing varied due to raining before land preparation and different farm plot. The soil was fertilized with $\mathrm{N}_{100} \mathrm{P}_{54} \mathrm{~K}_{167} \mathrm{~S}_{20} \mathrm{~B}_{1.7} \mathrm{~kg} \mathrm{ha}^{-1}$ and cow dung $5 \mathrm{t} \mathrm{ha}^{-1}$ (Mondal et al., 2011). The entire amount of cowdung, P, S, B and $1 / 2$ of $\mathrm{N}$ and $1 / 2$ of $\mathrm{K}$ were applied at the time of final land preparation. The remaining $\mathrm{N}$ and $\mathrm{K}$ were top dressed in equal two splits, at 25 and 50 days, after planting (DAP). The crops were weeded one time (20-25 days after clove emergence), while five times sprayed with Rovral, Antracol and Score for controlling purple blotch (Alternaria porri) and leaf burn (Fusarium oxysporum) diseases, as well as Tafgor 40 Ec, Admire and Vertimec were done to control thrips and mite. Irrigation was applied in four times at 15, 30, 45, and 60 days after planting (DAP). The crop was harvested on 21 March -
7 April, 2014, 1-9 April, 2015 and 10 March to 5 April, 2016. Data on different parameters like plant population, plant height, bulb length, bulb width, individual bulb wt. and bulb yield were recorded from $1 \mathrm{~m}^{2}$ in three areas from each treatment plot. Then it was computed and analyzed statistically using Statistics R package. The analyzed data was adjusted with Least Significant Difference (LSD) test at 5\% level. Per hectare gross return (GR), total cost (TC), total variable cost (TVC), gross margin (GM), net return (NR) and benefit cost ratio (BCR) were calculated on the basis of prevailing market price of the input and output.

$\mathrm{GR}=$ Return of main product $=$ Yield $\times$ price $(\mathrm{Tk}$.$) ; \mathrm{TC}=$ All input cost including rental value of land and interest on operating capital; TVC = All input cost except rental value of land; NR = GR TC; GM = GR - TVC

$$
\text { Benefit-Cost Ratio }=\frac{\text { Gross return }}{\text { Total cost }}
$$

\section{RESULTS AND DISCUSSION}

\section{Initial soil properties \\ of the experimental soil}

The soil analysis data revealed that all the nutrients were above the 
critical limit, except total nitrogen (Table 1). Organic matter was medium (2.02\%). The $\mathrm{pH}$ of the study soils is 7.93, indicated slightly alkaline. The texture of the soil was clay loam, with field capacity 28.5 to $29.3 \%$. As a whole, the soil is moderately good for garlic crop.

\section{Performance of yield contributing characters and bulb yield of garlic}

Interaction in between studies varieties $(\mathrm{V})$ and respective years $(\mathrm{Y})$, there were significant variations observed among the study traits except plant population and plant height (Table 2). Results revealed that BARI Rashun-1 $\left(\mathrm{V}_{1}\right)$ gave the maximum value, in respect of all the study traits, followed by BARI Rashun-2 $\left(\mathrm{V}_{2}\right)$ and the local cultivar $\left(\mathrm{V}_{3}\right)$. Least value was observed in local cultivar among all the characters. Similarly, among the study years $Y_{1}$ (2013-2014) produced the highest average value of the respective traits, as compared to $\mathrm{Y}_{2}$ (2014-2015) and $Y_{3}$ (2015-2016). However, crop duration ranged from 129-134 days, 125-126 days, and 118120 days, respectively, in $\mathrm{Y}_{1}, \mathrm{Y}_{2}$ and $\mathrm{Y}_{3}$. Likewise, plant population per meter squire ranged 46.32-47.95 (no.), 46.32-46.60 (no.) and 42.50-44.92 (no.); plant height ranged 54.00-68.67 $(\mathrm{cm})$, 52.67-69.14 (cm) and 51.33$64.17(\mathrm{~cm})$; bulb length ranged 2.95$3.02(\mathrm{~cm}), 2.57-2.82(\mathrm{~cm})$ and 1.95$2.43(\mathrm{~cm})$; bulb width ranged 2.94$2.98(\mathrm{~cm}), 2.55-2.77(\mathrm{~cm})$ and 1.902.36 (cm); individual bulb weight ranged 17.49-19.14(g), 15.96-17.18 (g) and 14.28-16.82 (g). It was noticed that $\mathrm{V}_{1}$ and $\mathrm{V}_{2}$ required 11-14 days and 6-7 days more crop duration than the local cultivar $\left(\mathrm{V}_{3}\right)$, and could easily be fitted in the existing farmers adorned cropping pattern (Garlic Jute - T. aman).

Among the tested garlic varieties, the bulb yield varied significantly from each others (Fig. 2). However, BARI Rashun-1 gave the maximum bulb yield (8.92 $\left.\mathrm{t} \mathrm{ha}^{-1}\right)$, compared to BARI Rashun-2 (8.29 $\left.\mathrm{t} \mathrm{ha}^{-1}\right)$ and local cultivar (7.99 $\left.\mathrm{t} \mathrm{ha}^{-1}\right)$. Garlic is sensitive to water stress. Due to water stress garlic loses bulb yield of 60$70 \%$ (Islam et al., 2012). Adequate supply of water during the growing period increased considerable amount bulb yield (Islam and Zaman, 2017). In the present study, bulb yield produced maximum $\left(9.48 \mathrm{tha}^{-1}\right)$ in the year of $\mathrm{Y}_{1}$ (Fig. 3). It might be due to this year received maximum seasonal rainfalls $(121 \mathrm{~mm})$, as compared to year 2014-2015 (92 $\mathrm{mm}$ ) and 20152016 (58 mm), which responsible of higher yield.

Concerning the interaction of garlic variety and year, there was also a significant effect observed in respect of bulb yield of garlic (Table 2). Results seem that significantly highest bulb yield was obtained from BARI Rashun-1 with three consecutive years, as compared to other cultivars. On the contrary, year $\mathrm{Y}_{1}$ was the top bulb yield producer than $Y_{2}$ and $Y_{3}$, in respect of all the varieties. BARI Rashun-1 produced 3, 8 and 12\% higher bulb yield than BARI Rashun-2, while 7, 12 and $20 \%$ higher than the local 
cultivar, respectively in $\mathrm{Y}_{1}, \mathrm{Y}_{2}$ and $\mathrm{Y}_{3}$. Significantly higher bulb yield potential of BARI Rashun-1 variety might be attributed to higher plant height, bulb length, bulb width and individual bulb weight. Similar findings were reported by Mozumder et al. (2015). Islam et. al., (2015) reported that the highest yield was recorded in BARI Rashun-2 and it was followed by BARI Rashun-1 and local.

Table 2 - Yield and yield contributing characters of garlic varieties under High Ganges River Floodplain soil (AEZ-11) in Kushtia District (pooled average of 2013-14, 2014-15 and 2015-16)

\begin{tabular}{|c|c|c|c|c|c|c|c|}
\hline $\begin{array}{c}\text { Inter } \\
\text { actions }\end{array}$ & $\begin{array}{c}\text { Crop } \\
\text { duration } \\
\text { (day) }\end{array}$ & $\begin{array}{c}\text { Plant } \\
\text { population } \\
\left(\text { no. } \mathrm{m}^{-2}\right)\end{array}$ & $\begin{array}{c}\text { Plant } \\
\text { height } \\
\text { (cm) }\end{array}$ & $\begin{array}{c}\text { Bulb } \\
\text { length } \\
\text { (cm) }\end{array}$ & $\begin{array}{c}\text { Bulb } \\
\text { width } \\
\text { (cm) }\end{array}$ & $\begin{array}{c}\text { Individual } \\
\text { bulb } \\
\text { weight } \\
\text { (g) }\end{array}$ & $\begin{array}{c}\text { Bulb } \\
\text { Yield } \\
\left(\mathrm{t} \mathrm{ha}^{-1}\right)\end{array}$ \\
\hline$Y_{1} \times V_{1}$ & 131.00 & 47.95 & 68.67 & 3.02 & 2.98 & 19.14 & 9.80 \\
\hline$Y_{1} \times V_{2}$ & 124.67 & 46.55 & 66.70 & 2.82 & 2.77 & 17.18 & 9.48 \\
\hline$Y_{1} \times V_{3}$ & 118.67 & 44.92 & 64.17 & 2.43 & 2.36 & 16.62 & 9.15 \\
\hline $\mathrm{Y}_{2} \times \mathrm{V}_{1}$ & 129.57 & 46.32 & 54.00 & 2.97 & 2.94 & 18.67 & 8.61 \\
\hline $\mathrm{Y}_{2} \times \mathrm{V}_{2}$ & 125.28 & 46.32 & 52.67 & 2.74 & 2.73 & 17.24 & 7.95 \\
\hline $\mathrm{Y}_{2} \times \mathrm{V}_{3}$ & 118.32 & 42.90 & 51.33 & 2.13 & 2.03 & 16.82 & 7.71 \\
\hline$Y_{3} \times V_{1}$ & 133.83 & 47.60 & 68.44 & 2.95 & 2.94 & 17.49 & 8.34 \\
\hline$Y_{3} \times V_{2}$ & 126.00 & 46.60 & 69.14 & 2.57 & 2.55 & 15.96 & 7.43 \\
\hline$Y_{3} \times V_{3}$ & 119.67 & 42.50 & 66.22 & 1.95 & 1.90 & 14.28 & 6.96 \\
\hline $\begin{array}{c}\text { LSD } \\
(0.05)\end{array}$ & 1.34 & 2.55 & 2.25 & 0.14 & 0.13 & 0.72 & 0.35 \\
\hline CV (\%) & 0.91 & 4.73 & 3.06 & 4.60 & 4.25 & 3.61 & 3.54 \\
\hline LS & $\star \star *$ & ns & ns & $\star \star$ & $\star \star \star *$ & * & * \\
\hline
\end{tabular}

LS = level of significance; $\mathrm{ns}=$ non significant at $p=0.05$; *significant at $p=0.05$; ** significant at $p=0.01$; ${ }^{* *}$ significant at $p=0.001 ; Y_{1}=$ Year 2013-14, $Y_{2}=2014-15$; $\mathrm{Y}_{3}=$ 2015-16; $\mathrm{V}_{1}=$ BARI Rashun-1, $\mathrm{V}_{2}=$ BARI Rashun -2 and $\mathrm{V}_{3}=$ local cultivar

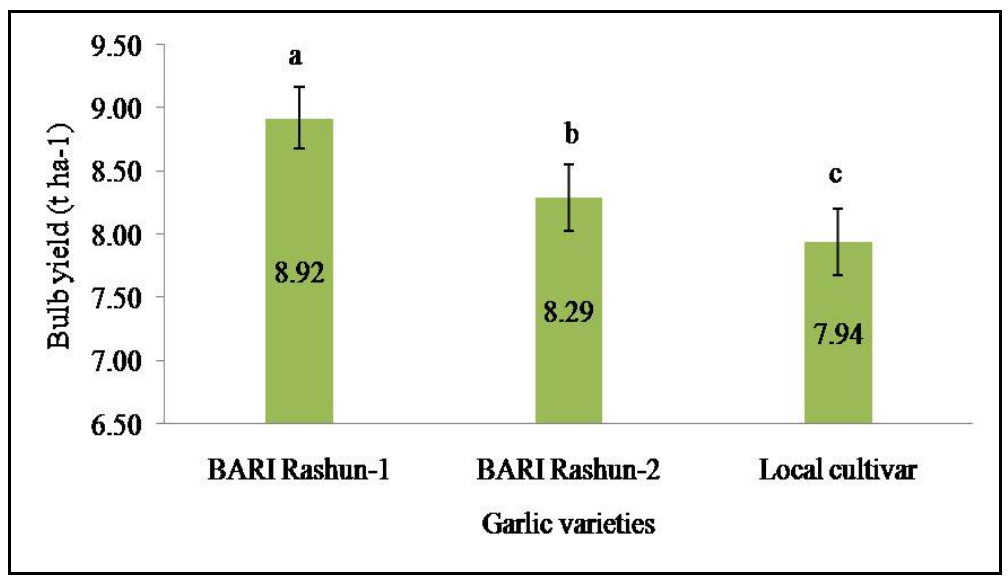

Figure 2 - Bulb yield of garlic due to different tested varieties 


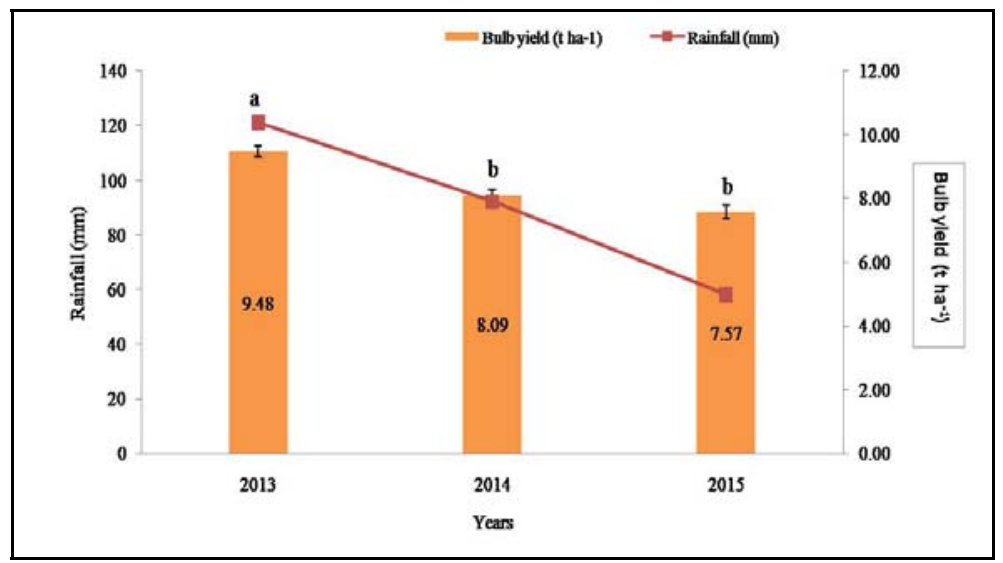

Figure 3 - Bulb yield of garlic in relation to rainfall at different tested years

\section{Correlation study}

Correlation coefficient among different characters has been presented in Table 3. Bulb yield obtained positive response in all the characters, whereas significant positive correlation showed only with bulb length $\left(0.67^{*}\right)$ and individual bulb weight $\left(0.74^{*}\right)$. Individual bulb weight showed significant positive correlation almost all the characters except crop duration (0.66) and plant height $(r=-0.18)$. Bulb width showed a strong positive and significant relationship in all the traits, except plant height and bulb yield. Bulb length showed a positive and significant relationship in all the traits, except plant height. Plant height showed positive and insignificant relationship almost entire the study traits, except individual bulb weight where obtained negative association. Except plant height and bulb yield, plant population showed positive and significant relationship in all the study traits. Crop duration showed positive and significant relationship with plant population, bulb length and bulb width, whereas insignificant observed in rest of the traits.

\section{Functional relationship of different yield contributing traits on bulb yield of garlic}

The functional linear analysis was performed using the three years pooled data of yield contributing characters along with the bulb yield. From the relationship it was displayed that the studied traits had positive contribution on the bulb yield, which indicated that the bulb yield was dependent on those traits. To evaluate the role of those traits, linear regressions were done. The results exposed that yield contributing characters like crop duration, plant population, plant height, bulb length, bulb width, individual bulb weight accounted for 12, 36, 0.05, 45, 41 and $55 \%$ of the total bulb yield variation, respectively (Fig. 4). 
M.S. RAHMAN, M.T. ISLAM, NC. SHIL, M. H. RAHMAN, M. JAHANGIR ALAM, M.R. ISLAM

Table 3 - Correlation among the studies traits

\begin{tabular}{cccccccc}
\hline & CD & PP & PH & BL & BW & IBWt & BY \\
\hline CD & 1 & & & & & & \\
\hline $\mathrm{PP}$ & $0.87^{\star \star}$ & 1 & & & & & \\
\hline $\mathrm{PH}$ & 0.29 & 0.36 & 1 & & & & \\
\hline $\mathrm{BL}$ & $0.87^{\star \star}$ & $0.95^{\star \star \star}$ & 0.15 & 1 & & & \\
\hline $\mathrm{BW}$ & $0.89^{\star \star}$ & $0.96^{\star \star \star}$ & 0.16 & $0.99^{\star \star \star}$ & 1 & & \\
\hline $\mathrm{IBWt}$ & 0.66 & $0.71^{\star}$ & -0.18 & $0.85^{\star \star}$ & $0.82^{\star \star}$ & 1 & \\
\hline $\mathrm{BY}$ & 0.35 & 0.60 & 0.22 & $0.67^{\star}$ & 0.64 & $0.74^{\star}$ & 1 \\
\hline
\end{tabular}

*significant at $=0.05$; ${ }^{*}$ significant at $=0.01 ;{ }^{* * *}$ significant at $=0.001$;

$\mathrm{CD}=$ crop duration; $\mathrm{PP}=$ plant population; $\mathrm{PH}=$ plant height; $\mathrm{BL}=$ bulb length; $\mathrm{BW}=$ bulb width; IBWt = individual bulb weight; $\mathrm{BY}=$ bulb yield

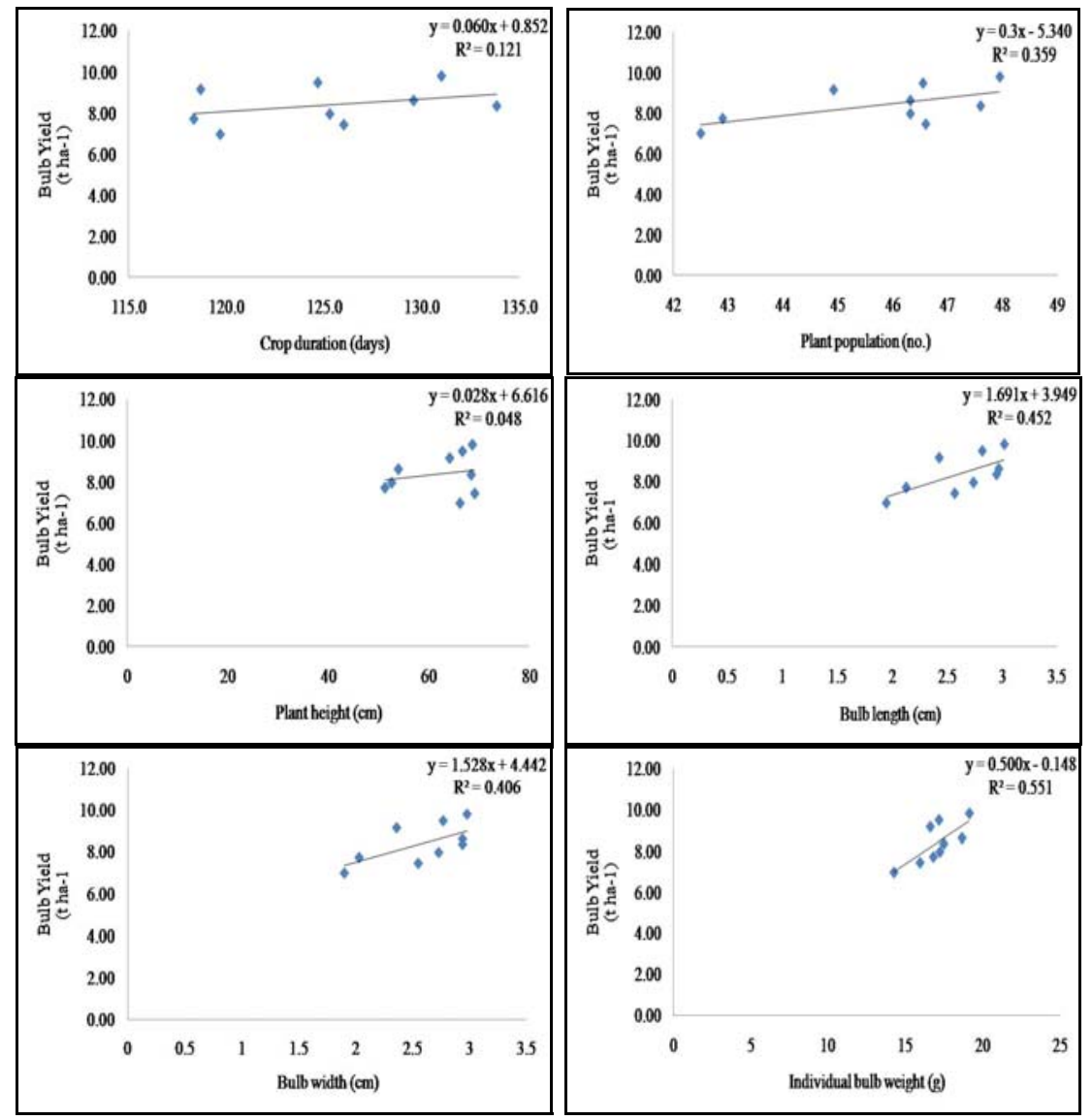

Figure 4 - Relationship of different yield contributing traits (bottom) on bulb yield of garlic 


\section{Cost, return and profitability of garlic varieties}

Cost is calculated on the basis of total cost (TC) and total variable cost (TVC), which includes labour, land preparation, seed, fertilizer and manure, irrigation, pesticides, interest on operating capital and rental value of land. Three years average cost is presented in Table 4. The average TVC of BARI Rashun-1, BARI Rashun-2 and the local cultivar were calculated at Tk. $144275 \mathrm{ha}^{-1}$, Tk. $143827 \mathrm{ha}^{-1}$ and Tk. $141281 \mathrm{ha}^{-1}$, respectively, while, TC was Tk. $163025 \mathrm{ha}^{-1}$ for BARI Rashun-1, Tk. $162577 \mathrm{ha}^{-1}$ for BARI Rashun-2, Tk. $160031 \mathrm{ha}^{-1}$ for the local cultivar.
Returns from BARI Rashun-1 was the highest (GR: Tk. 363700 ha $^{-1}$, GM: Tk. $219425 \mathrm{ha}^{-1}$ and NR: Tk. 200675 ha $^{-1}$ ) among all other varieties, due to its higher yield, and it was followed by BARI Rashun-2 (GR: Tk. 348210/ha and GM: Tk. 204382/ha and NR: Tk. $185633 \mathrm{ha}^{-1}$ ). The least return was in the local cultivar (GR: Tk. 329310 ha $^{-1}$, GM: Tk. 188029 ha $^{-1}$ and NR: Tk. 169279 $\mathrm{ha}^{-1}$ ). Benefit cost ratio (BCR) was also the highest in BARI Rashun-1 (2.23), followed by BARI Rashun-2 (2.14) and the local cultivar (2.06). This finding was supported by Khatun et al., (2014).

Table 4 - Cost, return and profitability of different garlic varieties at farmers field (three years average)

\begin{tabular}{ccccccc}
\hline Varieties & $\begin{array}{c}\text { Gross } \\
\text { return } \\
\left.\text { (Tk ha }^{-1}\right)\end{array}$ & $\begin{array}{c}\text { Total } \\
\text { cost } \\
\left.\text { (Tk ha }^{-1}\right)\end{array}$ & $\begin{array}{c}\text { Total } \\
\text { variable cost } \\
\left.\text { (Tk ha }^{-1}\right)\end{array}$ & $\begin{array}{c}\text { Gross } \\
\text { margin } \\
\left.\text { (Tk ha }^{-1}\right)\end{array}$ & $\begin{array}{c}\text { Net return } \\
\left.\text { (Tk ha }^{-1}\right)\end{array}$ & $\begin{array}{c}\text { Benefit } \\
\text { cost } \\
\text { ratio } \\
\text { (BCR) }\end{array}$ \\
\hline BARI Rashun-1 & 363700 & 163025 & 144275 & 219425 & 200675 & 2.23 \\
\hline BARI Rashun-2 & 348210 & 162577 & 143827 & 204383 & 185633 & 2.14 \\
\hline Local cultivar & 329310 & 160031 & 141281 & 188029 & 169279 & 2.06 \\
\hline
\end{tabular}

Price: garlic as seed: TK $100 \mathrm{~kg}^{-1}$; garlic as consumption: TK $42 \mathrm{~kg}^{-1}$; labour: Tk.250/day/capita

\section{CONCLUSION}

Regarding the bulb yield, BARI Rashun-1 appeared as promising in terms of their higher bulb yield potential and more economic return in comparison to existing local cultivar grown successfully in calcareous soil under High Ganges River Floodplain (AEZ-11) in Bangladesh. The variety BARI Rashun-1 had produced the highest plant height, bulb length, bulb width and individual bulb weight under calcareous soil. On account of gross return, gross margin, net return and benefit cost ratio, BARI Rashun-1 variety performed better than other cultivars. So, farmers that have land with calcareous soil could cultivate BARI Rashun-1 variety for higher bulb yield and economic profitability.

\section{REFERENCES}

Babaji, B.A. (1996). Effect of plant spacing and Nitrogen fertilizer on 
growth and yield of garlic. M.Sc. Thesis submitted to the Postgraduate School, ABU, Zaria, Nigeria.

BBS. (2018). Yearbook of agricultural statistic, 2017. Bangladesh Bureau of Statistics (BBS), Statistics and Informatics Division, Ministry of Planning, Government of the People's Republic of Bangladesh.

Bose, T.K. \& Som, G.M. (1990). Vegetablecrops in India. Naya Prokash, Calcutta, India, pp. 583601.

FAOSTAT (2016). Food and Agriculture Organization of the United Nations. Production Crops.

FRG (2012). Fertilizer recommendation guide, Bangladesh Agricultural Research Council (BARC), Farmgate, Dhaka 1215, p. 275.

Islam, M.A., Hossain, M.M., Alam, M.A., Islam, M., Khan, M.S.I., Ahmed, M.M., Uddin, K. \& Goshwami, B.K. (2015). On-farm verification trial of garlic varieties. Annual Research Report 2015. Spices Research Centre, Bangladesh Agricultural Research Institute, Bogra, Bangladesh, pp. 19-21.

Islam, M.R., Uddin, M.K., Mian, M.A.K.,Rahman, M.T. \& Hossain, J. (2012). Effect of different levels of irrigation and sulphur fertilizer on the bulb yield of garlic under zero tillage mulched cultivation. Bangladesh Agron. J.,15(2): 75-82.

Islam, M.R., Uddin, M.K., Mian, M.A.K., Zaman, R. \& Hossain, J. (2015). Performance of garlic (Allium sativum L.) genotypes after transplant aman rice harvest under zero tillage mulched condition. Int.J. Appl.Sci.Biotechnol., 3(1): 26-30, DOI: 10.3126/ijasbt.v3i1.11216

Islam, M.R. \& Zaman, R.U. (2017). Response of garlic yield and storability to varying frequencies of irrigation. Agric. Conspec.Sci., 82(1): 7-11

Khatun, M.U.S., Ferdous, M.Z., Islam, M.K. \& Anowar, M.M. (2014). Performance of some high yielding garlic varieties at two locations of Bangladesh. J. Bangladesh Agril.Univ., 12(2): 235-239.

Kurian, J.C. (1995). Plant that heal. Oriental Watchman Publishing House, Pune, India, p.31.

Mondal, M.R.I., Islam, M.S., Jalil, M.A.B., Rahman, M.M., Alam, M.S. \& Rahman, M.H.H. (Eds.) (2011). Krishi Projukti Hatboi (Handbook of Agro-technology), $5^{\text {th }}$ Edition, Bangladesh Agricultural Research Institute, Gazipur, Bangladesh, pp. 182-185.

Mozumder, S.N., Haque, M.I., Ara, R. \& Akter, S. (2015). Evaluation of garlic germplasm. Annual Research Report 2015. Spices Research Centre, Bangladesh Agricultural Research Institute, Bogra, Bangaladesh, pp. 26-28.

Rahman, M.S. \& Islam, M.T. (2016). Performance of garlic varieties. Annual Research Report 2015-16. On-Farm Research Division, Bangladesh Agricultural Research Institute, Kushtia, pp. 37-38. 